\title{
A fascinating book about ethnography made public and the ethnography of publicization
}

Book

Reviewed by

Abstract

Keywords

DOI
Fassin, D., ed. (2017). If Truth Be Told: The Politics of Public

EthNOGRAPHY. DURHAM, NC, U.S.A.: DUKE UNIVERSITY PRESS.

\section{Karen Mogendorff}

If Truth Be Told is a collection of essays on the politics of public ethnography and focuses on seasoned anthropologists' reflexive and critical engagement with public responses to their monographs. Fassin's primary purpose is to provide an ethnography of publicization. The book illuminates how public responses reflect and are affected by hegemonic sociopolitical realities and sociocultural practices and impact on the life and work of anthropologists. Of special interest is to what effect contributors take up different roles such as the role of expert to advocate for a more nuanced, non-hegemonic and contextualized understanding of marginalized people or specific groups.

Public engagement with science and technology; Science and media; Science and policy-making

https://doi.org/10.22323/2.17010702

If Truth Be Told is a well-written and edited collection of essays on the politics of public ethnography. The book focuses on seasoned anthropologists' reflexive and critical engagement with public responses to their publications, particularly politicization of their work. The book is divided in three parts - strategies, engagements and tensions - totaling 12 chapters, the introduction and epilogue by the book editor, Didier Fassin, not included. The essays vary widely in their geographical and thematic focus; together they cover different continents and various societal institutions, phenomena and processes such as the French welfare state, Palestinian charity organizations in trials in the US, migration and 'honor' killings in Scandinavia and peacemaking processes in Haiti. Each contribution offers fascinating insights into the authors' ethnographic research, how the ethnographic research is taken up or (mis)represented, how public (mis)use of ethnographic study affects the authors personally or professionally, and what anthropological insights may be gleaned from public actors' engagement with ethnographies. The book may be of interest to both social scientists working in a 
particular area of ethnographic research covered, as well as social scientists interested in politicization of ethnographic work. The contributions do not provide clear-cut answers or directives but may stimulate reflection on and analysis of how one's own ethnographic work may be taken up by different publics.

Didier Fassin does not plead for a greater presence of social scientists in the public sphere, but rather calls for 'a reflexive analysis of what becomes of our work once it is published' (p. 316) which does not necessarily mean that ethnographers should start to think about the public life of their work after the research has finished, or as Fassin states: 'the fate of the text after publications is highly dependent on what happened before'(p. 332). Still, he refers to public ethnography as the public afterlife of ethnographies. The book primary purpose is to generate ethnographic insights based on critical reflection and much less about how public responses may be deployed to improve research and outreach practices.

The conceptualization of public ethnography as afterlife may perhaps in part explain why ethnographers working in science communication or the STS subfield of public understanding of science are not included in the volume. Engagement with publics is for these scholars at the heart of their research, not something that comes after all work has been completed.

What constitute the publics of ethnographies appears to be rather broadly conceptualized in If Truth Be Told although individual contributions vary on this point. Public in the volume as a whole appears to correspond with engagement with non-anthropologists, including informants (participants in the ethnographic study) and researchers with other disciplinary backgrounds with whom authors collaborated. For instance, the contribution of João Biehl entitled Ethnography prosecuted focuses on conflicts in the collaborative project with other researchers and policy makers that occurred mostly before publication. This broad conceptualization contrasts with understandings of 'the public' that do not include co-participants in research projects or academics more generally, which means that some of the chapters may appeal to social scientists who engage in ethnographic action research.

The collection is not only broader but also narrower in its scope through its focus on politicization. The subjects and themes of ethnographic inquiry described tend to be politically relevant and potentially explosive in nature; it concerns research conducted within conflict areas or investigations that touch upon human rights, or criticize existing hegemonic relationships or the functioning of major institutions. Despite the nature of most of the ethnographic research described, authors pay relatively little attention to whether and how they anticipated public responses, how their expectations affected their research design, fieldwork relations, the use of different (social) media or how their expectations differed from actual responses. It remains largely unclear whether, if the authors had formulated things differently, they would have garnered other responses from publics. After all, no text is entirely neutral, ethnographies included. One and the same nuanced and contextualized ethnographic description may be communicated in various ways, and, as such, solicit divergent responses. Fassin appears to be an exception in this regard, he is very concrete when it comes to how he adapted his communication style based on his previous experiences in order to stimulate that his ethnographic findings are represented in the media as much as possible as he intended. 
Norwegian anthropologist Unni Wikan is also clearer on this point than most, perhaps because Norwegian academic anthropology has retained a relatively great presence and visibility in the public sphere.

Of special interest are the essays of contributors who used their expertise for other purposes than ethnographic writing. Kelly Gillespie focuses on her role as an expert witness for the Commission in South-Africa and the difficulties she encountered in getting her nuanced and contextualized ethnographic findings accepted in a highly politicized context; Jonathan Benthall shares his critical reflections on his role as an expert on charity organizations during trails in the US. Gabriella Coleman as an intermediary between Anonymous and journalists, provides insight into her dealings with people from the press and how she tries to correct inaccurate media portrayals and understandings of Anonymous based on her ethnographic work with this digital movement.

All in all, If Truth Be Told sheds light upon the role ethnography may play in the public sphere and how anthropologists struggle to communicate their nuanced, context-sensitive and often non-hegemonic ethnographic findings. Perhaps most of all, Fassin's collection shows that anthropology and ethnography matters. Public responses may at times be frustrating, painful, gratifying or inspiring; However, the fact that people respond to ethnography demonstrates that anthropology need not be marginal as a discipline and that studying public responses to ethnography is a worthwhile endeavor. It is now waiting for a book that primarily focuses on how critical reflection on public engagement may increase ethnographers' capacity to engage in dialogue with publics and how public responses may be deployed to increase the quality of conducted ethnographic work.

Author

Karen Mogendorff is an anthropologist, communication scientist and discursive psychologist with a Ph.D. in the Social Sciences. She has a special interest in disability ethnography, science communication and transdisciplinary research. E-mail: kmogendorff@hotmail.com.

\section{How to cite}

Mogendorff, K. (2018). 'A fascinating book about ethnography made public and the ethnography of publicization'. JCOM 17 (01), R02.

https://doi.org/10.22323/2.17010702.

(C) The Author(s). This article is licensed under the terms of the Creative Commons Attribution - NonCommercial - NoDerivativeWorks 4.0 License.

ISSN 1824-2049. Published by SISSA Medialab. jcom.sissa.it 